\title{
Correlates of hornbill distribution and abundance in rainforest fragments in the southern Western Ghats, India
}

\author{
T. R. SHANKAR RAMAN and DIVYA MUDAPPA
}

\section{Summary}

The distribution and abundance patterns of Malabar Grey Hornbill Ocyceros griseus and Great Hornbill Buceros bicornis were studied in one undisturbed and one heavily altered rainforest landscape in the southern Western Ghats, India. The Agasthyamalai hills (Kalakad-Mundanthurai Tiger Reserve, KMTR) contained over $400 \mathrm{~km}^{2}$ of continuous rainforest, whereas the Anamalai hills (now Indira Gandhi Wildlife Sanctuary, IGWS) contained fragments of rainforest in a matrix of tea and coffee plantations. A comparison of point-count and line transect census techniques for Malabar Grey Hornbill at one site indicated much higher density estimates in point-counts $\left(118.4 / \mathrm{km}^{2}\right)$ than in line transects $\left(51.5 / \mathrm{km}^{2}\right)$, probably due to cumulative count over time in the former technique. Although line transects appeared more suitable for long-term monitoring of hornbill populations, point-counts may be useful for large-scale surveys, especially where forests are fragmented and terrain is unsuitable for line transects. A standard fixed radius point-count method was used to sample different altitude zones $(600-1,500 \mathrm{~m})$ in the undisturbed site ( 342 point-counts) and fragments ranging in size from 0.5 to 2,500 ha in the Anamalais (389 point-counts). In the fragmented landscape, Malabar Grey Hornbill was found in higher altitudes than in KMTR, extending to nearly all the disturbed fragments at mid-elevations (1,000-1,200 m). Great Hornbill persisted in the fragmented landscape using all three large fragments ( $>200 \mathrm{ha})$. It was also recorded in four of five medium-sized fragments (25-200 ha) and one of five small fragments $(<25$ ha), which was adjacent to shade coffee plantations. Abundance of Malabar Grey Hornbill declined with altitude and increased with food-tree species richness. Great Hornbill abundance increased with food-tree species richness, suggesting that maintenance of high diversity of hornbill food species in fragments is important for their persistence. It is likely that the smaller and less specialized Malabar Grey Hornbill will survive in disturbed and fragmented forest landscapes, while Great Hornbill is more vulnerable to habitat alteration. Protection and restoration of rainforest fragments and food-tree resources, besides protection of existing large fragments, will aid the conservation of hornbills in the region.

\section{Introduction}

Vast areas of unbroken rainforest, once the hallmark of the humid tropics, are increasingly becoming landscapes of the past. Around the world, tropical forests, valued by biologists and conservationists for their remarkable diversity of life, have also attracted developers, ranchers, loggers, farmers, settlers, and a variety of other users who have exploited these forests, converted them to other land 
uses, or otherwise caused immense habitat alterations. Increasingly, modern tropical rainforest landscapes contain small, often highly disturbed vestiges of the earlier vast forest tracts, embedded in a sea of man-altered habitats, due to the ubiquitous process of fragmentation (Laurance and Bierregaard 1997).

Understanding the effects of such anthropogenic habitat change on distribution and abundance patterns of plant and animal species is a prerequisite to planning for their conservation. Among animal taxa, species of large body size, requiring large areas to meet their home range requirements, and species that are predominantly frugivorous or carnivorous, may be particularly susceptible to habitat fragmentation (Terborgh and Winter 1980). Bird species such as hornbills that are relatively large-bodied and frugivorous may thus be expected to suffer disproportionately. A number of studies have addressed the effects of habitat alteration due to selective logging and agro-forestry plantations on hornbills and found that hornbills tend to persist in disturbed habitats, although possibly at lower densities (Johns 1987, Lambert 1992, Thiollay 1995, Datta 1998, Marsden and Pilgrim 2003). There have, however, been few studies examining the effects of habitat fragmentation on hornbill biology and conservation. Nevertheless, in one such study, O'Brien et al. (1998) found that Sumba Wreathed Hornbills Aceros everetti tended to occur primarily in forest patches $>1,000$ ha in area and were influenced by forest structure and habitat disturbance.

In this study, we explored the effects of habitat fragmentation on hornbills in the Anamalai hills of the Western Ghats mountain range in south-western India. The Western Ghats is a global biodiversity hotspot (Olson and Dinerstein 1998, Myers et al. 2000) and an endemic bird area (Stattersfield et al. 1998). Much of the biological diversity, particularly of endemics, in the Western Ghats is found in tropical rainforests. Historically, forest loss to logging, conversion to agroforestry plantations, and developmental activities have severely reduced and fragmented these forests (Nair 1991). It has been estimated that, between 1920 and 1990, the natural vegetation of the Western Ghats has declined by $40 \%$, resulting in a four-fold increase in the number of fragments and an $83 \%$ reduction in size of surviving forest patches (Menon and Bawa 1997).

We examined hornbill distribution and abundance patterns in two contrasting landscapes: a relatively undisturbed, large $\left(>400 \mathrm{~km}^{2}\right)$ tract of rainforest in the Kalakad-Mundanthurai Tiger Reserve and a highly fragmented system of rainforest patches embedded in a matrix of plantations in the Anamalais. The study focused on Malabar Grey Hornbill Ocyceros griseus, a Western Ghats endemic, and Great Hornbill Buceros bicornis, the only two hornbill species occurring here, both considered to be Endangered in India (Anonymous 1994). Malabar Grey Hornbill and Great Hornbill are two of the largest birds in the rainforests of the Western Ghats. They are good indicators of the state of the rainforests as they have highly specialized requirements such as large nesting trees and largeseeded lipid-rich fruit (Leighton 1982, Kemp 1995, Kannan and James 1997, Mudappa and Kannan 1997, Mudappa 2000, Datta 2001). We examined the influence of forest area, altitude, and habitat characteristics on hornbills and discuss the results in terms of their implications for conservation of hornbills in fragmented landscapes. 


\section{Study areas}

Kalakad-Mundanthurai Tiger Reserve

The Kalakad-Mundanthurai Tiger Reserve (KMTR, $8^{\circ} 25^{\prime}-8^{\circ} 53^{\prime} \mathrm{N}$ and $77^{\circ}$ $10^{\prime}-77^{\circ} 35^{\prime}$ E) is the southernmost Tiger Reserve in Tamil Nadu State, India, lying at the southern extremity of the Western Ghats. The altitude of the Reserve ranges from 50 to $1,600 \mathrm{~m}$ above mean sea level, with rainforests occurring chiefly above $600 \mathrm{~m}$. The mean annual temperature in the rainforest ranges between 24 and $30^{\circ} \mathrm{C}$, and annual rainfall from $750 \mathrm{~mm}$ in the rain shadow regions of the (lower) eastern slopes to over 3,000 $\mathrm{mm}$ in the western parts. KMTR contains a significant part of one of the largest remaining contiguous tracts of tropical rainforests in the Western Ghats, spreading over 400 $\mathrm{km}^{2}$, including the Ashambu range in adjacent Kerala state (Ramesh et al. 1997). To the north and west of this region are reserved forests and smaller sanctuaries (e.g. Srivilliputtur Wildlife Sanctuary) that contain patches of rainforest separated by deciduous forests, rubber plantations, highways and human settlements. The mid-elevation (700-1,400 m) rainforest classified as tropical wet evergreen forest (Champion and Seth 1968) falls under the Cullenia exarillata-Mesua ferrea-Palaquium ellipticum type, and has about $43 \%$ plant endemism (Pascal 1988). At least 2,000 plant species of the 3,500 found in the Western Ghats may occur in KMTR (Ganesh et al. 1996). Fourteen rainforest sites selected to span the altitudinal range were surveyed for hornbills within the contiguous rainforests of KMTR around base camps in Sengaltheri (800$1,250 \mathrm{~m})$, Kannikatti (550-1,000 m), and Kakachi (> 1,200 m), between the months of February and May in 1998 and 1999.

\section{The Anamalais}

In contrast to the vast, undisturbed stretches of rainforests in KMTR, the Anamalai Hills is a fragmented landscape, being a mosaic of man-made habitats and rainforest remnants. In the Anamalais, Indira Gandhi Wildlife Sanctuary (IGWS, $10^{\circ} 12^{\prime}-10^{\circ} 54^{\prime} \mathrm{N}$ and $76^{\circ} 44^{\prime}-77^{\circ} 48^{\prime}$ E) extends over an area of about $987 \mathrm{~km}^{2}$, ranging in altitudes between $200 \mathrm{~m}$ in the foothills and 2,500 $\mathrm{m}$ at the Akkamalai Hill. The mid-elevation vegetation has been identified as the Cullenia exarillataMesua ferrea-Palaquium ellipticum type (Pascal 1988), similar to that of KMTR. The extensive rainforests that once covered this landscape have been cleared since the 1850 s to establish tea Camellia sinensis, coffee Coffea arabica, cardamom Elettaria cardamomum and Eucalyptus plantations, for road and reservoir construction, and development of human settlements. Natural vegetation occurs as at least 30 fragments of between $<10$ ha and c. 2,500 ha in area (Umapathy and Kumar 2000). All small $(<25 \mathrm{ha})$ and a few medium sized (25-200 ha) fragments are privately owned, and being in close proximity to human settlements, are often degraded and underplanted with coffee and cardamom. Most of the large fragments $(>200$ ha) are protected as part of the IGWS by the Tamil Nadu Forest Department. In this study, 13 rainforest fragments of varying sizes ( 0.5 ha to 2,500 ha) and disturbance regimes were sampled in the Anamalais between January and May 2000 (Table 1). 
Table 1. Characteristics of rainforest fragments sampled in the Anamalais and effort in each.

\begin{tabular}{|c|c|c|c|c|c|}
\hline Fragment & Area (ha) & $\begin{array}{l}\text { Disturbance } \\
\text { level }\end{array}$ & Altitude (m) & $\begin{array}{l}\text { Number of } \\
\text { point-count } \\
\text { surveys }\end{array}$ & $\begin{array}{l}\text { Number of } \\
\text { hornbill } \\
\text { detections }^{\text {a }}\end{array}$ \\
\hline $\begin{array}{l}\text { Akkamalai-Iyerpadi } \\
\text { Complex }\end{array}$ & 2,500 & Low & $1,250-1,500$ & 75 & 1,2 \\
\hline Varagaliar & 2,000 & Low & $650-800$ & 30 & 13,0 \\
\hline Karian Shola & 500 & Low & 750 & 40 & 30,3 \\
\hline Andiparai & 200 & Medium & 1,250 & 42 & 0,2 \\
\hline Manamboli & 200 & Low & 800 & 45 & 14,2 \\
\hline Puthuthottam & 100 & High & $1, \mathrm{OOO}$ & 30 & 5,1 \\
\hline Korangumudi & 50 & High & $1, \mathrm{OOO}$ & 30 & 6,0 \\
\hline Tata Finley & 25 & High & 1,000 & 30 & 2,0 \\
\hline Pannimade & 10 & Low & 1,100 & 30 & 3,0 \\
\hline Varattuparai $1-3$ & 8 & High & 1,100 & 20 & 2,1 \\
\hline Varattuparai 4 & 3 & High & 1,020 & 6 & 1,0 \\
\hline Selaliparai I & 2.5 & High & 1,050 & 7 & - \\
\hline Selaliparai 2 & 1.5 & High & 1,050 & 4 & 1,0 \\
\hline
\end{tabular}

${ }^{a}$ Number of detections presented as Malabar Grey Hornbill, Great Hornbill.

\section{Methods}

\section{Bird surveys}

A fixed radius point-count method (Verner 1985, Hutto et al. 1986) was used to sample hornbills. Sampling was carried out at 342 points in KMTR (18-25 pointcount surveys at each of 14 sites) and 389 points in the Anamalais in 2000 (6-75 point-count surveys in each fragment in relation to fragment area, Table 1). Counts were of 5 min duration, starting from the time the observer reached the point. All hornbills seen, heard, or flying under the canopy (or $<5 \mathrm{~m}$ above) were recorded in the following distance bands $(\mathrm{m})$ : $0-5,5-10$, $10-15,15-20,20-30,30-40$ and $40-50$. Birds estimated to be beyond $50 \mathrm{~m}$ were not recorded and successive count stations on a given day were at least $100 \mathrm{~m}$ apart to avoid overlap. In smaller fragments, counts carried out on different days unavoidably overlapped to some extent. Counts were carried out between o6h3o and ogh3o during the breeding season (February-May; Kannan and James 1997, Mudappa 2000).

Data on line transects were collected for Malabar Grey Hornbill in one site, Karian Shola National Park in the Anamalais, in order to compare with point-count density estimates from the same site. Four line transects (length 1.00-1.74 km) totalling $5.40 \mathrm{~km}$ were walked along existing trails in the National Park. Each transect was walked between 07h30 and o9h3o. As in point-counts, this covered the period when Malabar Grey Hornbills were noticed to be most active in feeding and calling, and hence most likely to be recorded. The transects were walked at a slow, uniform rate of approximately $1 \mathrm{~km} / \mathrm{h}$, while carefully scanning the canopy for hornbills. Sampling was carried out between April 2 and April 5 1999, during the peak breeding season of hornbills (Mudappa and Kannan 1997, Mudappa 2000). All hornbills seen or heard immediately ahead or on either side of the transects were recorded. For each detection, the following parameters were noted: number 
of hornbills (where possible), whether seen or heard only, and perpendicular distance interval from the transect. The following perpendicular distance intervals $(\mathrm{m})$ were used: $0-10,10-20,20-30,30-40,40-50,50-75,75-100,100-150$. The distance classes further away were wider to minimize errors in distance estimation. Distances were estimated visually or by pacing.

\section{Vegetation}

A point-centred quarter (PCQ) method was used to estimate tree densities, and basal area in KMTR ( $n=182$ PCQs) as well as in other rainforest fragments, except Varagaliar in the Anamalais (Krebs 1989). From 10 to 30 PCQ samples were taken depending on the size of the fragment in the Anamalais. In three of the smaller fragments with dense tangled undergrowth, trees were counted in 10 5-m radius circular plots. For Varagaliar, tree densities and basal area were derived from published literature (Ayyappan and Parthasarathy 1999). Total tree and food-tree densities were estimated as they were considered to be probable indicators of habitat disturbance. Habitat structural parameters (canopy height and cover) within each site were estimated from measurements taken at 25 points, which were spaced at intervals of $50 \mathrm{~m}$. At each point, canopy height and canopy cover were measured, using a clinometer or a range finder and a spherical densiometer respectively.

\section{Analyses}

In point-count and line transect samples, many hornbill detections were made by calls alone due to the dense vegetation, which therefore often prevented individuals being counted in the field. Information on flock sizes obtained during supplementary observations in the study sites were used for such detections by randomly assigning a flock size from the sampling distribution of flock sizes. This allowed the estimation of the number of individual hornbills in each pointcount survey. The average number of hornbills per point was divided by the area sampled (o.7854 ha $\times$ number of counts) to obtain densities.

The computer program DISTANCE version 2.1 (Laake et al. 1994) was used to estimate density from the line transect data. Of four estimators tried, the HalfNormal model was selected on the basis of minimum Akaike information criterion (Buckland et al. 1993). This provided a good fit to the data on the number of hornbill detections as a function of distance from the transect $\left(\chi^{2}=2.33\right.$, $d f=6, P=0.89$ ).

Tree densities and basal areas were computed from the PCQ data. Using published information on Malabar Grey and Great Hornbills (Kannan 1994, Kannan and James 1997, Mudappa 2000) and personal observations, we estimated from these data the densities of trees that were breeding season food species of hornbills. Using the proportion of trees of different diameter size classes, we also estimated in each site the density of trees of three diameter size classes (30-60 cm, 60-90 cm, 90+ cm), as these may represent abundance of large trees and potential nesting trees (Kannan 1994, Mudappa and Kannan 1997). Average canopy cover and canopy height were calculated from the 25 readings taken in each site. 
We used Spearman's rank-correlations (Siegel and Castellan 1988) and multiple linear regressions (Zar 1999) to relate hornbill abundance to site and habitat parameters.

\section{Results}

\section{Hornbill distribution and abundance}

We recorded 17 detections (27 individuals) of Malabar Grey Hornbill in KMTR and 78 detections (98 individuals) in the rainforest fragments of the Anamalais. Great Hornbill was seen or heard at least once a week in KMTR, particularly in Kannikatti and Sengaltheri, between 600 and $1,300 \mathrm{~m}$ but was not detected during point-count sampling. In the Anamalais, we recorded Great Hornbills 11 times ( 15 individuals). Malabar Grey Hornbill occurred in 11 of the 13 rainforest fragments (Table 1). It was absent in the smallest fragment (Selaliparai 2) and was also not recorded in point-counts in Andiparai, one of the medium-sized fragments (although it was recorded here once during supplementary observations). Great Hornbill was recorded in six of the rainforest fragments in the Anamalais (and additionally during supplementary observations in two fragments: Varagaliar and Korangumudi). There was a clear pattern of increasing incidence of Great Hornbill from small fragments $(<25$ ha) to medium $(25-200$ ha) and large (> $200 \mathrm{ha}$ ) fragments. Great Hornbills were found in only $20 \%$ $(1 / 5)$ of the small fragments, $80 \%(4 / 5)$ of the medium-sized fragments, and $100 \%(3 / 3)$ of the large fragments.

Fixed-radius point-count densities of Malabar Grey Hornbills in the sites where they occurred ranged from 2.11 birds $/ \mathrm{km}^{2}$ in the Iyerpadi-Akkamalai complex to $118.41 / \mathrm{km}^{2}$ in Karian Shola. Densities of Great Hornbill ranged from $3.40 / \mathrm{km}^{2}$ in the Iyerpadi-Akkamalai complex to $9.55 / \mathrm{km}^{2}$ in Karian Shola. On the four replicate line transects in Karian Shola in 1999, we recorded 31 detections (flocks or solitary individuals) of Malabar Grey Hornbill. The mean encounter rate of Malabar Grey Hornbill was 5.74 detections $/ \mathrm{km}(\mathrm{CV}=17.8 \%$; $95 \%$ confidence interval $=3.27-10.07$ detections $/ \mathrm{km}$ ). The population density was found to be 51.5 hornbills $/ \mathrm{km}^{2}(\mathrm{CV}=25 \%$; $95 \%$ confidence interval $=29.9-88.4$ hornbills $/$ $\mathrm{km}^{2}$ ), considerably lower than the mean density of 118.4 birds $/ \mathrm{km}^{2}$ obtained using point-counts in 2000 .

\section{Comparison of vegetation parameters between KMTR and Anamalais}

With the exception of two large fragments, Akkamalai and Karian Shola, tree densities in all the rainforest fragments in the Anamalais were lower than in three sites in the rainforests of KMTR (Table 2). Basal area did not always correspond to tree densities, although Manamboli, Selaliparai 2, and Karian Shola had higher basal area estimates (114 $\mathrm{m}^{2} / \mathrm{ha}, 141.2 \mathrm{~m}^{2} / \mathrm{ha}$, and $96 \mathrm{~m}^{2} /$ ha, respectively) than sites in KMTR. The average canopy height varied between sites, particularly in the rainforest fragments, with the lowest in Varattuparai $(1-3 ; 17.4 \mathrm{~m})$ and the highest in Tata Finley $(31 \mathrm{~m})$. Canopy cover did not vary substantially between sites (68-98\%), with Puthuthottam (89\%) and Korangumudi (68\%) having the least canopy cover. Across all sites, these variables were, however, not signific- 
Table 2. Habitat structure measurements of different sites within the undisturbed rainforest of Kalakad-Mundanthurai Tiger Reserve (KMTR) and rainforest fragments in Anamalais. Tabled values are averages with SE in parentheses (except for food-tree density).

\begin{tabular}{|c|c|c|c|c|c|}
\hline Sites & $\begin{array}{l}\text { Tree density } \\
\text { (no./ha) }\end{array}$ & $\begin{array}{l}\text { Basal area } \\
\left(\mathrm{m}^{2} / \mathrm{ha}\right)\end{array}$ & $\begin{array}{l}\text { Canopy height } \\
(\mathrm{m})\end{array}$ & $\begin{array}{l}\text { Canopy cover } \\
(\%)\end{array}$ & $\begin{array}{l}\text { Food-tree } \\
\text { density/ha } \\
\text { (no. species) }\end{array}$ \\
\hline \multicolumn{6}{|l|}{ KMTR } \\
\hline Kakachi & $850.97(61.3)$ & $79.23(6.8)$ & $23.83(0.7)$ & 93.68 (o.8) & - \\
\hline Sengaltheri & $760.47(43.9)$ & $81.07(10.3)$ & 20.92 (0.9) & 93.84 (o.9) & - \\
\hline Kannikatti & $628.64(79.4)$ & $72.23(7.1)$ & $24.38(1.2)$ & 94.66 (o.6) & - \\
\hline \multicolumn{6}{|l|}{ ANAMALAIS } \\
\hline Akkamalai & $697(5.0)$ & 52.49 & $22.65(1.4)$ & $97.70(0.5)$ & $221(14)$ \\
\hline Varagaliar & 446 & 36.26 & $28.56(1.4)$ & $94.68(0.7)$ & $126(9)$ \\
\hline Karian Shola & $755(7.6)$ & 95.86 & $27.00(0.7)$ & $98.20(0.2)$ & $287(18)$ \\
\hline Andiparai & $431(4.4)$ & 84.49 & $22.66(1.8)$ & $96.24(0.7)$ & $186(16)$ \\
\hline Manamboli & $582(5.8)$ & 114.4 & $24.54(1.1)$ & $94.96(1.4)$ & $122(10)$ \\
\hline Puthuthottam & $239(2.4)$ & 52.49 & $22.70(1.9)$ & $89.00(1.3)$ & $98(7)$ \\
\hline Korangumudi & $196(1.9)$ & 31.25 & $20.74(2.1)$ & $68.24(3.2)$ & $72(11)$ \\
\hline Tata Finley & $331(5.6)$ & 40.31 & $31.32(1.9)$ & $96.32(1.2)$ & $55(7)$ \\
\hline Pannimade & $534(13.7)$ & $47 \cdot 48$ & $22.43(1.8)$ & 92.48 (o.8) & $107(6)$ \\
\hline Varattuparai 1-3 & $295(7.6)$ & 33.47 & $17.40(2.2)$ & 95.65 (o.9) & $66(7)$ \\
\hline Varattuparai 4 & 484 & 50.70 & $17 \cdot 75(2.2)$ & $78.10(2.6)$ & $115(7)$ \\
\hline Selaliparai I & 382 & 62.95 & $19.30(1.6)$ & $79.60(3.8)$ & $241(3)$ \\
\hline Selaliparai 2 & 424 & 141.2 & $17.80(1.0)$ & $86.50(4.2)$ & $198(3)$ \\
\hline
\end{tabular}

antly correlated to either fragment area or altitude. Only food-tree species richness was positively correlated to area of fragment $\left(r_{\mathrm{s}}=0.826, n=13, P=0.001\right)$.

\section{Correlates of hornbill abundance}

A primary correlate of Malabar Grey Hornbill distribution was altitude. This species was found to occur between 500 and $900 \mathrm{~m}$ altitude in KMTR (sporadically up to 1,100 m). In the Anamalais, the species was found frequently at altitudes up to $1,200 \mathrm{~m}$. In both study sites, the estimated Malabar Grey Hornbill density was inversely related to altitude (KMTR: $r_{\mathrm{s}}=-0.776, n=14, P=0.001$, between $550 \mathrm{~m}$ and 1,340 $\mathrm{m}$; Anamalais: $r_{\mathrm{s}}=-0.648, n=13, P=0.017$, between $650 \mathrm{~m}$ and $1,350 \mathrm{~m}$ ). The density of Great Hornbill across sites in the Anamalais was not correlated to altitude, and the species was seen at all altitudes from around $650-1,450 \mathrm{~m}$ (Figure 1).

Stepwise multiple regression showed that Malabar Grey Hornbill density across rainforest fragments was related negatively to altitude and positively with food-tree species richness of the fragments (adjusted $\mathrm{R}^{2}=0.794, F_{2,10}=24.08, P<$ 0.001, Table 3). Density of Great Hornbill across sites was also correlated positively to food-tree species richness (adjusted $\mathrm{R}^{2}=0.420, F_{1,11}=9.678, P=0.01$, Table 3). Across sites, densities of small ( $<60 \mathrm{~cm}$ diameter at breast height, dbh), medium-sized (60-90 cm dbh), and large ( $>90 \mathrm{~cm} \mathrm{dbh}$ ) trees varied considerably (Figure 2). These were, however, not significantly correlated to hornbill densities.

\section{Discussion}

Barring a single study, there have been no previous reported estimates of hornbill densities from Indian tropical rainforests derived using systematic line transect 

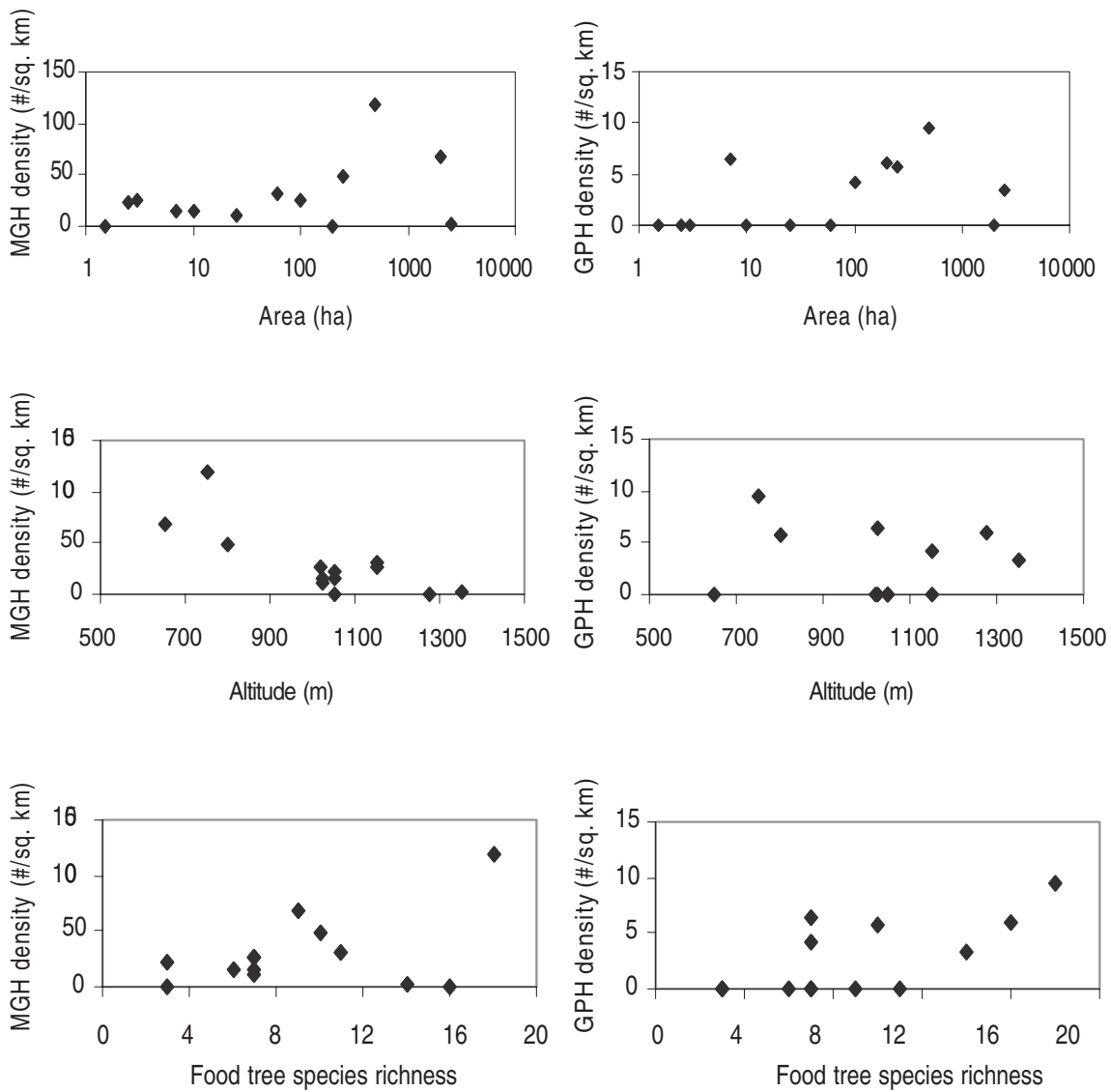

Figure 1. Densities of Malabar Grey Hornbill (MGH) and Great Hornbill (GPH) in relation to altitude, area and food-tree species richness in rainforest fragments in the Anamalai hills, Western Ghats, India. MGH density was significantly negatively related to altitude and positively to food-tree species richness. GPH density was positively related to food-tree species richness.

Table 3. Results of stepwise multiple regression models of hornbill densities in rainforest fragments on site and habitat parameters showing significant variables and parameter estimates.

\begin{tabular}{llrrrr}
\hline Species & Variables in model & \multicolumn{1}{l}{$\begin{array}{l}\text { Coefficient } \\
\text { B (SE) }\end{array}$} & $\begin{array}{l}\text { Standardised } \\
\text { coefficient } \\
\text { Beta }\end{array}$ & $t$ & $P$ \\
& & & & \\
\hline Malabar Grey & Constant & $135.7(24.2)$ & & 5.60 & 0.000 \\
Hornbill & Altitude & $-0.133(0.02)$ & -0.794 & -6.05 & 0.000 \\
& Number of food-tree species & $3.344(0.94)$ & 0.468 & 3.57 & 0.005 \\
Great Hornbill & Constant & $-1.776(1.61)$ & & -1.11 & 0.293 \\
& Number of food-tree species & $0.495(0.16)$ & 0.684 & 3.11 & 0.010 \\
\hline
\end{tabular}




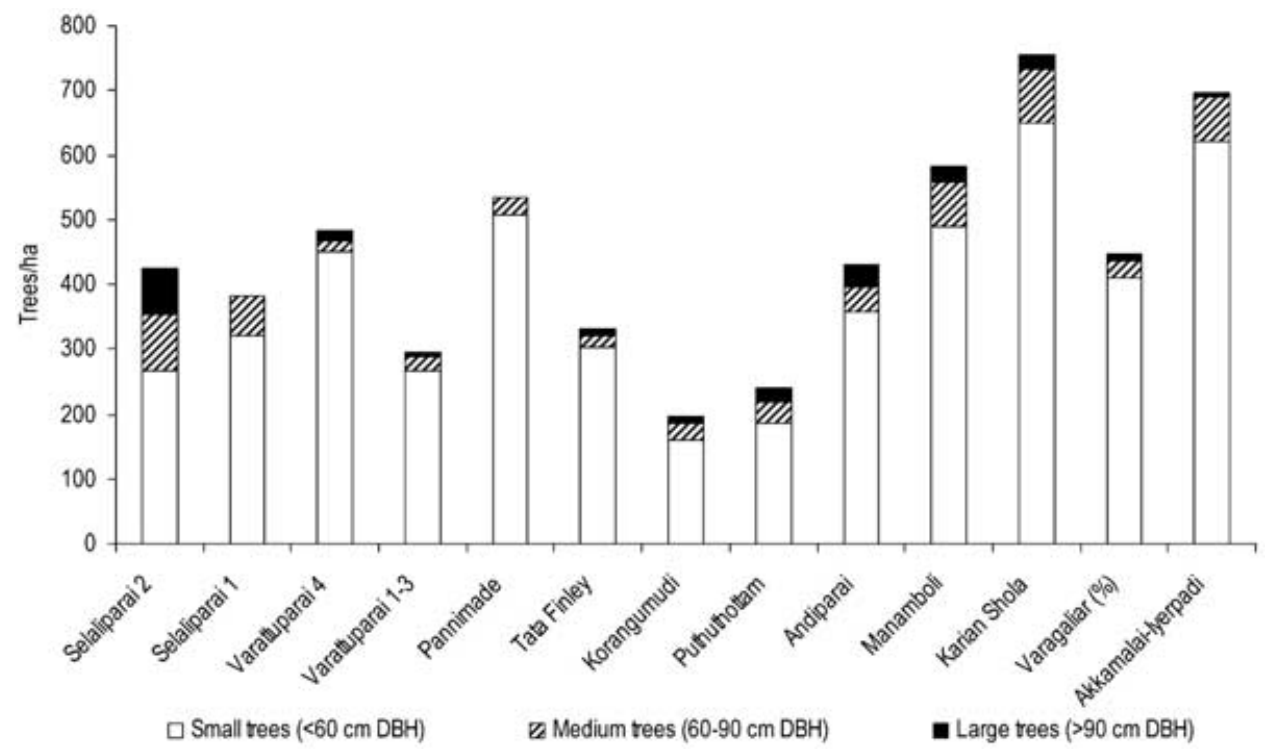

Figure 2. Densities of trees of different diameter size classes across the rainforest fragments in the Anamalai hills, Western Ghats, India. (Sites are arranged in increasing order of area from left to right; data for Varagaliar from Ayyappan and Parthasarathy 1999).

or point-count techniques. Reddy et al. (1990) used monthly strip transects to count Malabar Pied Hornbills Anthracoceros coronatus in tropical moist deciduous (three sites) and semi-evergreen and evergreen forest (two sites) in Uttara Kannada district, Karnataka. Their counts indicated low densities (0.5 - 2.3 birds/ $\mathrm{km}^{2}$ ) in all sites except a tropical moist deciduous site at Dandeli (36.2 birds/ $\mathrm{km}^{2}$ ). An earlier study from South-East Asia reported hornbill densities of 0.10$46.0 / \mathrm{km}^{2}$ for several species, and a maximum of $51.4 / \mathrm{km}^{2}$ for Red-knobbed Hornbill Aceros cassidix in Sulawesi (Kinnaird et al. 1996). Marsden and Pilgrim (2003) reported mean densities of Blyth's Hornbill Rhyticeros plicatus of 3-52 birds $/ \mathrm{km}^{2}$ in Papua New Guinea, and Marsden (1999) reported densities of Sumba Hornbill R. everetti ( $1.3-6.9$ birds $/ \mathrm{km}^{2}$ ) and of $R$. plicatus (25-26 birds/ $\mathrm{km}^{2}$ ). Anggraini et al. (2000) estimated densities of four species of hornbills in Sumatra to range between 1.9 and $7.9 \mathrm{birds} / \mathrm{km}^{2}$. Datta (1998) reported encounter rates of hornbills of 0.10 to 1.11 birds $/ \mathrm{km}$ in north-east India.

The densities and encounter rates obtained in this study fall largely within this range with the exception of Malabar Grey Hornbill densities in Karian Shola. In Karian Shola, an estimate of 51.5 hornbills $/ \mathrm{km}^{2}(5.74$ detections $/ \mathrm{km})$ was obtained using line transects, although this needs to be verified with more spatial and temporal replication. Notably, the point-count density estimate for Karian Shola was over twice as high $\left(118.4 / \mathrm{km}^{2}\right)$. For common birds, the point-count technique has been found to produce higher estimates of densities than line transects, due to the cumulative count over time ( $5 \mathrm{~min}$ ) of individuals at each point (Raman 2003). Nevertheless, the estimated Malabar Grey Hornbill population density was quite high for a large frugivorous rainforest bird, but could be 
attributed to the occurrence of favourable nesting sites, year-round food resources, and minimal disturbance in this area (Mudappa and Kannan 1997, Kannan 1998, Kannan and James 1999, Mudappa 2000). The results also underscore the importance of Karian Shola for hornbill conservation in the Anamalais and probably for the Western Ghats region.

The hornbill density estimate is, however, likely to be an underestimate as it excludes part of the population (nesting females incarcerated in their nests and hence not detected along transects). This can be corrected for if there are good data on population structure. For instance, comparing data on adult sex ratios just prior to and during the breeding season and availability of nest sites, one can estimate the proportion of breeding females in the population. The preliminary results reported here suggest that the line transect technique can be used to census and monitor hornbill populations in Karian Shola, although greater sampling effort would be required for Great Hornbill and for more precise estimates. Point counts may be used for large-scale surveys, especially in small patches and difficult terrain unsuitable for line transect surveys, although density estimates obtained by this method need to be used with caution.

An aspect of hornbill ecology that was not explored during this study was their local, regional, and seasonal movements. For one of the study sites (Karian Shola), Kannan (1998) has reported that Malabar Grey and Great Hornbills are breeding residents, with the former seen throughout the year with occasional influxes of individuals attracted to fruiting fig trees, and the latter being locally nomadic and exhibiting greater monthly fluctuations (Kannan 1998). Hornbills in other regions have been noted to migrate several hundred kilometres seasonally, probably due to fluctuations in fruit availability (Whitney et al. 1998, Holbrook and Smith 2000, H. Rainey pers. comm.). A better understanding of the effects of fragmentation would therefore require surveys of hornbills and food resource availability in all seasons in fragments and surrounding areas. Local movements were probably not the cause of the absence of Great Hornbill detections in pointcounts in KMTR. Being at the western extremity of their distributional range, they are intrinsically rare in this area, and were therefore less frequently encountered.

In comparison with KMTR, Malabar Grey Hornbill appeared to be more abundant and widespread altitudinally in the fragmented landscape, achieving relatively high densities even in small and medium-sized fragments. This could be attributed to the strong colonizing ability of this species, which is a relatively strong flier and has been observed flying over unsuitable habitat between fragments. This species is probably less specialized than Great Hornbill, as it uses smaller nesting trees (Mudappa and Kannan 1997), and also forages on fruits of understorey plants in addition to the canopy and mid-storey species (Mudappa 2000). In addition, the availability of fruiting food-tree species in the fragments (Table 2) and large trees with probable suitable nest cavities (Figure 2) has allowed the persistence of this rainforest endemic in the fragmented landscape. Abundance of Ficus trees appeared to be relatively high in the moderately or heavily disturbed fragments and the copiously fruiting Ficus trees attracted numerous Malabar Grey Hornbills and were a key resource for them. The importance of Ficus in the diet of hornbills has been noted (Kinnaird et al. 1996, 
Kannan and James 1997, Mudappa 2000), although hornbill abundances may (Kinnaird et al. 1996) or may not (Datta 1998) be directly related to Ficus abundance.

Comparing the distribution of the two hornbill species across the fragmented sites, it is clear that Great Hornbill appeared to be more susceptible to habitat fragmentation. Great Hornbill was seen in only a single small $(<25$ ha) fragment and four medium-sized fragments (25-200 ha). All but one were adjacent to fairly large coffee plantations that had fruiting native, exotic and Ficus shade trees in the canopy. During supplementary observations, Great Hornbill was seen in one of the other medium-sized fragments, Korangumudi, which was also surrounded by coffee plantations. It was not possible to confirm whether hornbills bred in the forest fragments. Among the fragments, breeding of both hornbill species has been confirmed in two large (Karian Shola, Varagaliar) and three medium-sized fragments (Manamboli, Puthuthottam and Korangumudi). In addition, we have observed Malabar Grey Hornbills to breed in two small fragments that were not among our intensive study sites. A more intensive study is required to see if hornbills breed in other rainforest fragments and this should be followed up by long-term monitoring of hornbill populations.

The vegetation in rainforest fragments was more degraded than in the relatively undisturbed large tract of rainforest in KMTR. However, the fragments contained many large remnant rainforest trees, suggesting the habitat was not yet so highly disturbed as to preclude use by hornbills. Nevertheless, none of the measured variables, except food-tree species richness, was significantly related to hornbill abundance. Food-tree species richness may be a particularly crucial aspect allowing the persistence of hornbills in the fragmented landscape as the availability of a diversity of food species is likely to signify a wider and yearround availability of food (Kannan and James 1999, Datta 2001). Such a diversity of food species is critical for the survival of hornbills, especially during the breeding season (Leighton 1982, Leighton and Leighton 1983, Kannan and James 1997, Mudappa 2000). Food-tree density itself is not significant since having very high densities of a few food species may still imply that when these species do not bear ripe fruit, hornbills may face local resource scarcity. In north-east India, Great Hornbill abundance was correlated to large tree density and basal area (Datta 1998). The different results obtained in this study suggest that hornbill distribution and abundance may vary in a site-specific manner. Great Hornbill was found to be the most common species of hornbill in north-east India (Datta 1998), while in the Western Ghats it was relatively rare.

The results emphasize the importance of large forest tracts for conservation of hornbills, particularly large species such as Great Hornbill, as observed in other studies (Poonswad and Tsuji 1994, O'Brien et al. 1998, M. F. Kinnaird pers. comm.). Our study also indicates, however, the value of small, isolated fragments, especially those surrounded by a matrix of habitats containing resources used by hornbills (Turner and Corlett 1996, Laurance and Bierregaard 1997). Such fragments may aid in maintaining larger populations of hornbills in the landscape, provide additional food resources, and increase connectivity between patches. Therefore, the conservation value of rainforest fragments should not be overlooked. 


\section{Acknowledgements}

We would like to thank Tamil Nadu Forest Department, particularly R. P. S. Katwal, A. Udhayan, and several range officers, for research permits, local support, and also their interest in the conservation of the hornbills. The manuscript improved immensely from the comments by Drs Margaret Kinnaird, Alan Kemp, Hugo Rainey, the editor, and an anonymous referee. Financial support was provided by Ministry of Environment and Forests, India, the John D. and Catherine T. MacArthur Foundation, and the Oriental Bird Club, U.K. We are grateful for encouragement and support by Drs Pilai Poonswad, R. Sukumar, N. V. Joshi, Ravi Chellam, Ajith Kumar and Ravi Sankaran. Our colleagues, P. Jeganathan, S. Narendra Babu, and P. R. Shankar, assisted with fieldwork.

\section{References}

Anonymous (1994) The Wildlife (Protection) Act, 1972. 3rd edition. Dehradun: Natraj Publishers.

Anggraini, K., Kinnaird, M. and O'Brien, T. (2000) The effects of fruit availability and habitat disturbance on an assemblage of Sumatran hornbills. Bird Conserv. Internatnl. 10: 189-202.

Ayyappan, N. and Parthasarathy, N. (1999) Biodiversity inventory of trees in a large-scale permanent plot of tropical evergreen forest at Varagalaiar, Anamalais, Western Ghats, India. Biodivers. Conserv. 8: 1533-1554.

Buckland, S. T., Anderson, D. R., Burnham, K. P. and Laake, J. L. (1993) Distance sampling: estimating abundance of biological populations. London: Chapman and Hall.

Champion, H. S. and Seth, S. K. (1968) A revised survey of the forest types of India. Delhi: Manager of Publication, Government of India.

Datta, A. (1998) Hornbill abundance in unlogged forest, selectively logged forest and a forest plantation in Arunachal Pradesh, India. Oryx 32: 285-294.

Datta, A. (2001) An ecological study of sympatric hornbills and fruiting patterns in a tropical forest in Arunachal Pradesh. PhD thesis, Saurashtra University, Rajkot, Gujarat.

Ganesh, T., Ganesan, R., Devy, M. S., Davidar, P. and Bawa, K. S. (1996) Assessment of plant biodiversity at a mid-elevation evergreen forest of Kalakad-Mundanthurai Tiger Reserve, Western Ghats, India. Curr. Sci. 71: 379-392.

Holbrook, K. M. and Smith, T. B. (2000) Seed dispersal and movement patterns in two species of Ceratogymna hornbills in a West African tropical lowland forest. Oecologia 125: 249-257.

Hutto, R. L., Pletschet, S. M. and Hendricks, P. (1986) A fixed-radius point-count method for nonbreeding and breeding season use. Auk 103: 593-602.

Johns, A. D. (1987) The use of primary and selectively logged rainforest by Malaysian hornbills (Bucerotidae) and implications for their conservation. Biol. Conserv. 40: 179190.

Kannan, R. (1994) Ecology and conservation of the Great Pied Hornbill (Buceros bicornis) in the Western Ghats of southern India. PhD thesis, University of Arkansas, Arkansas.

Kannan, R. (1998) Avifauna of the Anaimalai hills (Western Ghats) of southern India. J. Bombay Nat. Hist. Soc. 95: 193-214.

Kannan, R. and James, D. A. (1997) Breeding biology of the Great Pied Hornbill (Buceros bicornis) in the Anaimalai hills of southern India. J. Bombay Nat. Hist. Soc. 94: 451-465.

Kannan, R. and James, D. A. (1999) Fruiting phenology and the conservation of the Great Pied Hornbill (Buceros bicornis) in the Western Ghats of southern India. Biotropica 31: $167-177$. 
Kemp, A. C. (1995) The hornbills. Oxford: Oxford University Press.

Kinnaird, M. F., O’Brien, T. G. and Suryadi, S. (1996) Population fluctuation in the Sulawesi Red-knobbed Hornbills: tracking figs in space and time. Auk 113: 431-440.

Krebs, C. J. (1989) Ecological methodology. New York: Harper and Row.

Laake, J. L., Buckland, S. T., Anderson, D. R. and Burnham, K. P. (1994) DISTANCE user's guide version 2.1. Fort Collins, CO: Colorado Coop. Fish and Wildlife Research Unit, Colorado State University.

Lambert, F. R. (1992) The consequences of selective logging for Bornean lowland forest birds. Phil. Trans. R. Soc. Lond. B 335: 443-457.

Laurance, W. F. and Bierregaard, R. O. Jr., (eds). (1997) Tropical forest remnants: ecology, management, and conservation of fragmented communities. Chicago, IL: University of Chicago Press.

Leighton, M. (1982) Fruit resources and patterns of feeding, spacing and grouping among sympatric hornbills (Bucerotidae). PhD dissertation, University of California, Davis, CA.

Leighton, M. and Leighton, D. R. (1983) Vertebrate responses to fruiting phenology within a Bornean rain forest. Pp. 181-196 in S. L. Sutton, T. C. Whitmore and A. C. Chadwick, eds. Tropical rain forest: ecology and management. Oxford: Blackwell Scientific.

Marsden, S. J. (1999) Estimation of parrot and hornbill densities using a point-count distance sampling method. Ibis 141: 377-390.

Marsden, S. J. and Pilgrim, J. D. (2003) Factors influencing the abundance of parrots and hornbills in pristine and disturbed forests on New Britain, PNG. Ibis 145: 45-53.

Menon, S. and Bawa, K. S. (1997) Applications of Geographical Information Systems, remote sensing and a landscape ecology approach to biodiversity conservation in the Western Ghats. Curr. Sci. 73: 134-145.

Mudappa, D. (2000) Breeding biology of the Malabar Grey Hornbill (Ocyceros grisues) in southern Western Ghats, India. J. Bombay Nat. Hist. Soc. 97: 15-24.

Mudappa, D. and Kannan, R. (1997) Nest-site characteristics and nesting success of the Malabar Gray Hornbill in the southern Western Ghats, India. Wilson Bull. 109: 102-111.

Myers, N., Mittermeir, R. A., Mittermeir, C. G., da Fonseca, G. A. B. and Kent, J. (2000) Biodiversity hotspots for conservation priorities. Nature 403: 853-858.

Nair, S. C. (1991) The southern Western Ghats: a biodiversity conservation plan. New Delhi: INTACH.

O'Brien, T. G., Kinnaird, M. F., Jepson, P. and Setiwan, I. (1998) Effect of forest size and structure on the distribution of Sumba Wreathed Hornbills Aceros everetti. Pp. 209-218 in P. Poonswad, ed. The Asian Hornbills: ecology and conservation. Bangkok: Biodiversity Research and Training Program, Thai Studies in Biodiversity 2.

Olson, D. M. and Dinerstein, E. (1998) The Global 200: a representation approach to conserving the Earth's most biologically valuable ecoregions. Conserv. Biol. 12: 502-515.

Pascal, J. P. (1988) Wet evergreen forests of the Western Ghats of India: ecology, structure, floristic composition and succession. Pondicherry: French Institute.

Poonswad, P. and Tsuji, A. (1994) Ranges of males of the Great Hornbill Buceros bicornis, Brown Hornbill Ptilolaemus tickelli, and Wreathed Hornbill Rhyticeros undulatus in Khao Yai National Park, Thailand. Ibis 136: 79-86.

Raman, T. R. S. (2003) Assessment of census techniques for interspecific comparisons of tropical rainforest bird densities: a field evaluation in the Western Ghats, India. Ibis 145: 9-21.

Ramesh, B. R., Menon, S. and Bawa, K. S. (1997) A vegetation-based approach to biodiversity gap analysis in the Agasthyamalai region, Western Ghats, India. Ambio 26: 529236.

Reddy, M. S., Muralidhar, K. S., Gandhi, M. R. and Basalingappa, S. (1990) Distribution and variation in number of Malabar Pied Hornbills Anthracoceros coronatus (Boddaert) 
in a selected area of North Kanara forest of Western Ghats in Karnataka (India). Indian Zool. 14(1\&2): 63-73.

Siegel, S. and Castellan, N. J. (1988) Nonparametric statistics for the behavioural sciences. Second edition. New York: McGraw Hill.

Stattersfield, A. J., Crosby, M. J., Long, A. J., and Wege, D. C. (1998) Endemic bird areas of the world: priorities for biodiversity conservation. Cambridge, U.K.: Birdlife International.

Terborgh, J. W. and Winter, B. (1980) Some causes of extinction. Pp. 119-33 in M. E. Soulé and B. A. Wilcox, eds. Conservation biology: an evolutionary-ecological perspective. Sunderland, MA: Sinauer Associates.

Thiollay, J. M. (1995) The role of traditional agroforests in the conservation of rain forest bird diversity in Sumatra. Conserv. Biol. 9: 335-353.

Turner, I. M. and Corlett, R. T. (1996) The conservation value of small isolated fragments of lowland tropical rain forest. Trends Ecol. Evol. 8: 330-333.

Umapathy, G. and Kumar, A. (2000) The occurrence of arboreal mammals in the rain forest fragments in the Anamalai Hills, south India. Biol. Conserv. 92: 311-319.

Verner, J. (1985) Assessment of counting techniques. Curr. Ornithol. 2: 247-302.

Whitney, K. D., Fogiel, M. K., Lamperti, A. M. Holbrok, K. M., Stauffer, D. J., Hardesty, B. D., Parker, V. T. and Smith, T. B. (1998) Seed dispersal by Ceratogymna hornbills in the Dja Reserve, Cameroon. J. Trop. Ecol. 14: 351-371.

Zar, J. H. (1999) Biostatistical analysis. Fourth edition. Englewood Cliffs, NJ: Prentice-Hall.

\section{T. R. SHANKAR RAMAN,}

Centre for Ecological Research and Conservation, 3076/5, IV Cross, Gokulam Park, Mysore 570002, India (present address) and Centre for Ecological Sciences, Indian Institute of Science, Bangalore 560012, India.

DIVYA MUDAPPA ${ }^{1}$

Centre for Ecological Research and Conservation, 3076/5, IV Cross, Gokulam Park, Mysore 570002, India. E-mail: podocarp@vsnl.net

${ }^{1}$ Author for correspondence.

Received 9 April 2002; revision accepted 8 April 2003 